\title{
Dynamic Analysis of Structural Shifts of Fiscal Revenue in Nigeria, 1999-2016
}

\author{
Mustapha A. Akinkunmi ${ }^{1}$ \\ ${ }^{1}$ Ministry of Finance, Lagos State, Nigeria \\ Correspondence: Mustapha A. Akinkunmi, Ministry of Finance, Lagos State Government, Alausa-Ikeja, Nigeria. \\ Tel: 234-803-535-2900. E-mail: aakinkunmi@yahoo.com; maakinresearch@gmail.com
}

Received: August 22, 2016

Accepted: September 23, 2016

Online Published: October 25, 2016

doi:10.5539/ijef.v8n11p96

URL: http://dx.doi.org/10.5539/ijef.v8n11p96

\begin{abstract}
The oil sector that eased the financial constraint of Nigerian government in the 1970s is presently acting as the source of financial constraints to the country due to a continuous decline in government revenue, arising from the recent drastic fall in world crude oil prices. This calls for the government to diversify its revenue base through improving taxation. This study examined the influence of economic performance on the government revenue as well as the various sources of tax revenues in Nigeria. Monthly data spanning 1999 to 2016 were utilized to estimate vector error correction models (VECM) for five sources of government tax revenues based on data availability. Empirical results revealed that there is a significant relationship between real GDP and real company income tax revenues, and between real GDP and real excise duty revenues in the long run. However, in the short run, the one-year lag of tax revenue varieties poses a significant influence on the various sources of tax revenues.
\end{abstract}

Keywords: government revenue, VECM, company income tax, excise duty, GDP

\section{Introduction}

Over a decade ago, a greater number of countries in sub-Sahara Africa witnessed huge fiscal deficits arising from a rapid increase in expenditure and a continuous fall in revenue (Nashashibi \& Bazzoni, 1994). However, endogenous growth theories point out that economic growth can be enhanced by alleviated fiscal disequilibrium through either reducing spending or raising revenue (Tanzi \& Zee, 1997). Of recent, Khwaja and Iyer (2014) concluded by suggesting areas of further research. First is to examine how the performance of tax revenue is influenced by the structure and content of public expenditure. Second is to test the validity of the hypothesis that the perception of the fairness of government spending can affect compliance behaviour. Third is to investigate how tax revenue performance is influenced by the tax structure (the composition of different taxes in the revenue basket) in a given country. Therefore, this study intends to fill the research gap by critically analyzing the structural shift of government revenue in Nigeria in order to provide a well-designed and robust policy direction to enhance tax revenue performance.

The agricultural sector plays a dynamic role in boosting Nigeria's economic growth after its independence in 1960. From the 1950s to early 1960s, the sector was the engine through which government programs were executed. However, the agriculture's role was suddenly transformed as a result of the country's civil war (1967-1970) that hindered the capacity of its economy, and led to a decline in most of the macroeconomic variables.

The country faced a challenge of the absence of resources to resuscitate the economy after the end of the civil war in 1970. This situation would have continued if the 1970s oil price shock in the global market had not occurred. The rise in the world crude oil price due to the Middle East crisis in 1973/74 provided the financial resources to the country that eased the financial constraint of government. Owing to this, macroeconomic variables such gross domestic product (GDP), investment, revenue etc., as well as the economic performance of the country, were significantly improved by the emergence of the oil sector (Egwaikhide, 1987).

The oil sector that removed the financial constraint of Nigerian government in the 1970s is presently acting as the source of financial constraints to the country due to a continuous decline in government revenue, arising from the recent drastic fall in world crude oil price in the Mid-year 2014. This calls for the government to 
diversify its revenue base through improving taxation.

In the light of this, the study intends to analyze the structural shifts of government revenue in the country. The outcomes of the study will provide policy directions to Nigerian government on how to optimally diversify its sources of revenues in order to prevent the occurrence of the economic crises witnessed of recent. Section 2 provides stylized facts about the sources of government revenue in Nigeria. Section 3 reviews the relevant existing studies in relation to government tax revenue. Section 4 provides analytical framework and methodology. Section 5 presents results as well as discussion in the study. Section 6 offers the conclusion and policy implications.

\section{Stylized Facts of Nigerian Government Revenue}

Nigerian government revenue recorded a significant increase as well as a dramatically structural change since the country's independence in 1960. For instance, between 1961 and 1965, the mean yearly growth rate of indirect tax revenue was 10 percent and later rose to about 24 percent between 1976 and 1980. Similarly, direct taxes witnessed an average annual growth rate of 9.9 percent and 28 percent respectively, and the non-tax revenue also grew significantly in the same period.

The direct tax revenue accounted for the highest growth rate during the 1970s oil shock but it did not present the dynamic pattern of revenue structure in the country. The structural changes are best revealed by examining the absolute magnitude of the various types of federal government revenue and their contributions to total federally collected revenue over the years. The direct tax revenue increased from N15.2 million in 1961 to about N9.2 billion in 1980. Similarly, the share of direct tax revenue to total government revenue rose from about 6.8 percent in 1961 to almost 60.1 percent in 1980. Indirect tax revenue recorded a value of N160.1 million in 1961 with about 71.8 percent contribution to the total government revenue. Its value increased to N1.8 billion in 1980 but its share of the total government revenue reduced sharply to less than 12 percent in the same year. For the case of non-tax revenue, the Nigerian government received a huge amount of money mainly from the emergence of oil. These changes in government revenue along with government spending substantially increased the relevance of fiscal operations in the entire economy (Egwaikhide, 1987).

\subsection{Determinants of Growth and Structural Changes in Government Revenue}

Over the reviewed period, several factors contributed the growth of government revenue in Nigeria. The first oil shock in the 1970s was identified as the one most important driver, which backed a structural shift from indirect to direct tax revenue. Between 1961 and 1971, indirect taxes were the largest source of government revenue which is mainly generated from the export duties. Prior to 1972, the value of export duties generated was influenced by the performance of agricultural sector as well as the global prices of export goods and the prices offered to the farmers by the marketing boards (Fajana, 1979 as cited in Egwakhide, 1987).

The need to improve the level of development as indicated in the launch of the first National Development Plans in 1962 led to the direction of fiscal policy towards making funds available for economic development through raising the existing tax rates especially indirect taxes in the area of import duties. Concomitantly, more policy focuses were also placed on import substitution (IS) strategy as tools for achieving economic development. This gave birth to high protective tariffs in the country, which invariably translates into increased revenue for the federal government during the early 1960s.

Government measures put in place to hinder imports and reduce consumer demand came in the pattern of high customs duties. Higher excise duties were also imposed on selected local manufactured commodities, and excise duty was extended to other goods in order to widen its base. These measures contributed to a rise in the share of indirect taxes to 73 percent in 1965 . However, the share of excise duties was very small because of the poor industrial base. For this period, the bulk of government revenue was generated from external trade sector.

In the late of 1960s, the government came up with several measures in order to raise funds to finance the civil war that commenced in 1967. Although a dramatic fall in revenue from customs and excise duties as well as a great disruption hindering the country's productive capacity. For example, the share of the agricultural sector in the economy declined from 64.1 percent in 1960 to 37.4 percent in 1970. In addition, between 1967 and 1969 , the sector's export experienced the average annual growth rate of -0.5 percent.

The measures put in place in this period include the following: imposing a 20 percent tax on profits realized from the disposal of assets; charging additional profit tax of 20 kobo; and raising rates on customs duties as well as on some selected locally made goods (Aboyade \& Ayida, 1971).

In the 1970s, the country witnessed a significant expansion of government revenue and a dramatic change in its revenue structure. Since 1974, the indirect tax that accounted for the largest in the 1960s was relegated to the 
nadir position. The direct tax took the leading role in terms of its contribution to the government revenue. This dynamic situation was attributable to the emergence of the 1970s global oil shock. Nigerian economy was mainly driven by the oil sector in the period, with the neglect of agricultural sector which is the biggest employer of labour. The agriculture found it difficult to supply adequate food needed by the rapidly increasing population as well as raw materials for industrial production. This led to the massive importation of food items worth of about N1.5 billion in 1980, and depletion of the country's foreign reserves to a pathetic level in the early 1980s. In addition, there was a big decline in revenue generated from export duties from N41.9 million in 1970 to nearly N0.1 million. The condition was extremely worse as a result of unfavourable trends in the global market prices for export products.

On the other hand, revenue from import duties increased from N215.5 million in 1970 to more than N1.4 billion in 1980, reflecting the magnitude of the country's imports (increasing from N756.4 million in 1970 to N9.8 billion in 1980). Figuratively, since 1966 revenue from import duties has outweighed the indirect tax revenue. This indicates that import substitution policy did not have an influence on the entire economy because of the country increased dependence on imports. In addition, the policy had led to an increase in the country's reliance on the foreign sector at the expense of the domestic economy. This implies that the policy of import substitution industrialization is not the solution for the problem of under-development (Ekuerhare, 1983; Eleazu, 1984).

The policy of trade liberalization was responsible for the significant loss of government revenue from import duties between 1973 and 1977 (Falegan, 1979). However, the increased performance of the industrial sector in the 1970s contributed to a remarkable improvement in the revenue generated from excise duties.

Therefore, the unexpected shift in revenue from indirect to direct taxes is associated with the oil boom. This implies that the indirect taxes would have retained their 1960s position in terms of revenue contribution in the absence of oil. Direct taxes such as company and personal income taxes have never been the main sources of federal government revenue since the 1960s. This vividly replicates the stage of development in the country.

By 1972, domination of revenues from direct taxes in relation to other sources of government revenue was manifested. Compositionally, petroleum profits tax accounted for the largest share of the total direct tax revenues. For instance, the share of petroleum profit tax to total revenue increased from 15.4 percent in 1970 to about 54 percent by 1980 .

Revenue from oil sector accounted for only 8 percent of total government revenue in 1961, rose significantly to 26.3 percent in 1970 and constituted 84 percent by 1979. At present, oil revenue still dominates the government income. In absolute magnitude, oil revenue increased from N17.1 million in 1961 to N166.4 million in 1970 and to N6 billion in 1977. The country realized more than N9.1 million from oil in 1981. However, the presence of fiscal indiscipline during the oil boom era led to persistent and rising budget deficits, inflationary crisis, and failure to diversify the revenue base.

In 1999, the Nigerian government collected monthly revenue of N44 billion in which oil revenue accounted for about 50 percent while the remaining was generated from non-oil sources. The total federally collected revenue rose to N102 billion on a monthly average in 2000, then to about N618 billion in 2014. However, the amount of monthly average government revenue declined to about N423 billion as a result of a substantial fall in the global crude oil prices. As at of May 2016, the federal government revenue recorded about N401 billion on a monthly average (See Table 1).

In terms of government revenue structure, the share of oil revenue to total federally collected revenue ranged between 50 percent and 80.5 percent on a monthly average, while non-oil revenue accounted for 50 percent during the period 1999-2016. In addition, the contribution of oil revenue to total revenue in Nigeria recorded a peak of 80.5 percent in 2001 but the lowest of 53.4 percent in 2015, whereas non-oil revenue sources attained their peak with 50 percent in 1999 and lowest with 19.5 percent in 2000 (Table 1 and Figure 1). 
Table 1. Structure of government revenue in Nigeria 1999-2016

\begin{tabular}{cccc}
\hline Year & $\begin{array}{c}\text { Oil revenue } \\
(\%)\end{array}$ & $\begin{array}{c}\text { Non-Oil Revenue } \\
(\%)\end{array}$ & $\begin{array}{c}\text { Total Federally collected revenue } \\
\text { (N'Billion) }\end{array}$ \\
\hline 1999 & 50.0 & 50.0 & 44.14654 \\
2000 & 82.2 & 17.8 & 102.6807 \\
2001 & 80.5 & 19.5 & 102.1036 \\
2002 & 77.6 & 22.4 & 115.8347 \\
2003 & 76.8 & 23.2 & 163.2243 \\
2004 & 80.4 & 19.6 & 218.4441 \\
2005 & 79.5 & 20.5 & 240.0058 \\
2006 & 79.6 & 20.4 & 266.0175 \\
2007 & 75.0 & 25.0 & 300.2089 \\
2008 & 74.8 & 25.2 & 364.8738 \\
2009 & 58.6 & 41.4 & 281.2997 \\
2010 & 68.8 & 31.2 & 415.9208 \\
2011 & 69.7 & 30.3 & 497.2766 \\
2012 & 68.5 & 31.5 & 532.4102 \\
2013 & 68.3 & 31.7 & 580.5051 \\
2014 & 65.9 & 34.1 & 618.7499 \\
2015 & 53.4 & 46.6 & 423.087 \\
$2016 *$ & 54.9 & 45.1 & 401.7766 \\
\hline
\end{tabular}

Note. * end at May 2016.

Source: Computed by Author.

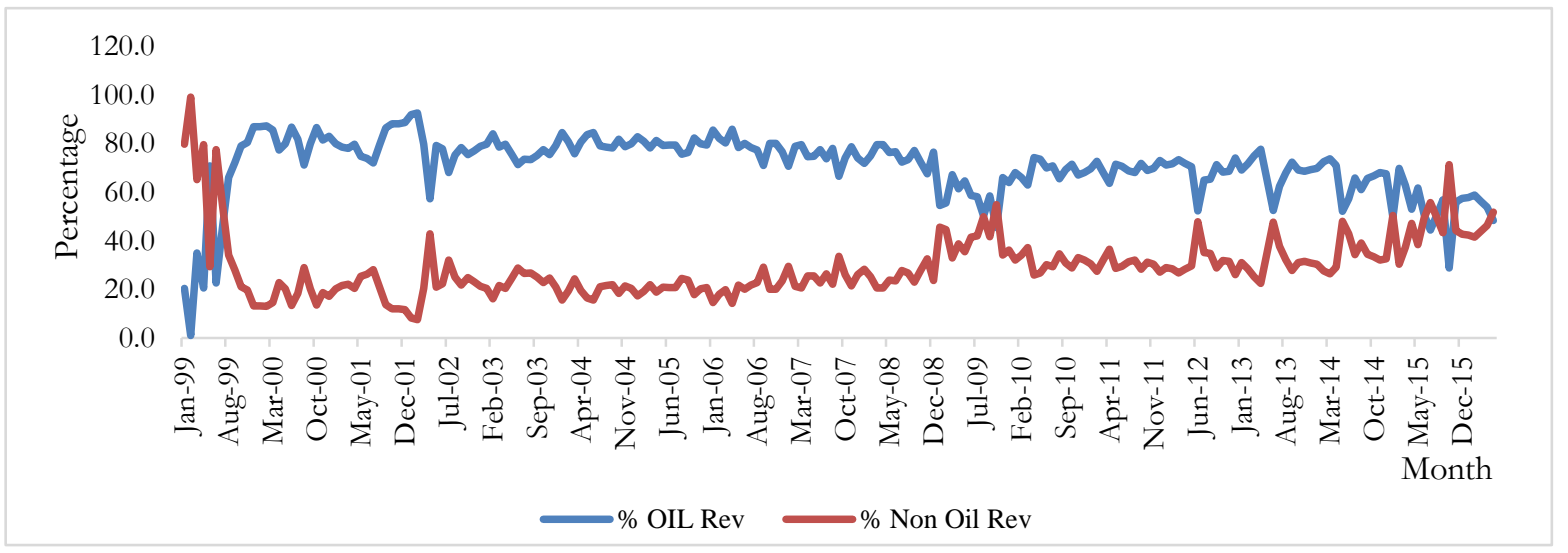

Figure 1. Monthly revenue composition in Nigeria

Source: Author's compilation.

In relation to the share of tax component revenue to the aggregate federally collected revenue, direct tax revenue in forms of gross petroleum profit tax (gppt) and company income tax accounted for the minimum of 5 percent of the total government revenue in Nigeria from 1999 to 2016. However, the least contribution from indirect tax such as custom import duty, excise duty and value-added tax to the government revenue was 0.5 percent for the same period (Figure 2).

In 1999, customs import duty's share to federally collected revenue was about 25 percent compared to value added tax (12\%), gross petroleum profit tax (10\%), and company income tax $(9.8 \%)$ and excise duty $(0.2 \%)$ respectively. However, from 2000 onwards, gross petroleum profit tax took a leading role by contributing nothing less than 15 percent to the federal government revenue on a monthly average. The share of gross petroleum profit tax recently recorded a decline to the extent that value-added tax's contribution plays a leading role in 2016 (Figure 2). This indicates the existence of structural dynamics in terms of government tax revenue in Nigeria. 


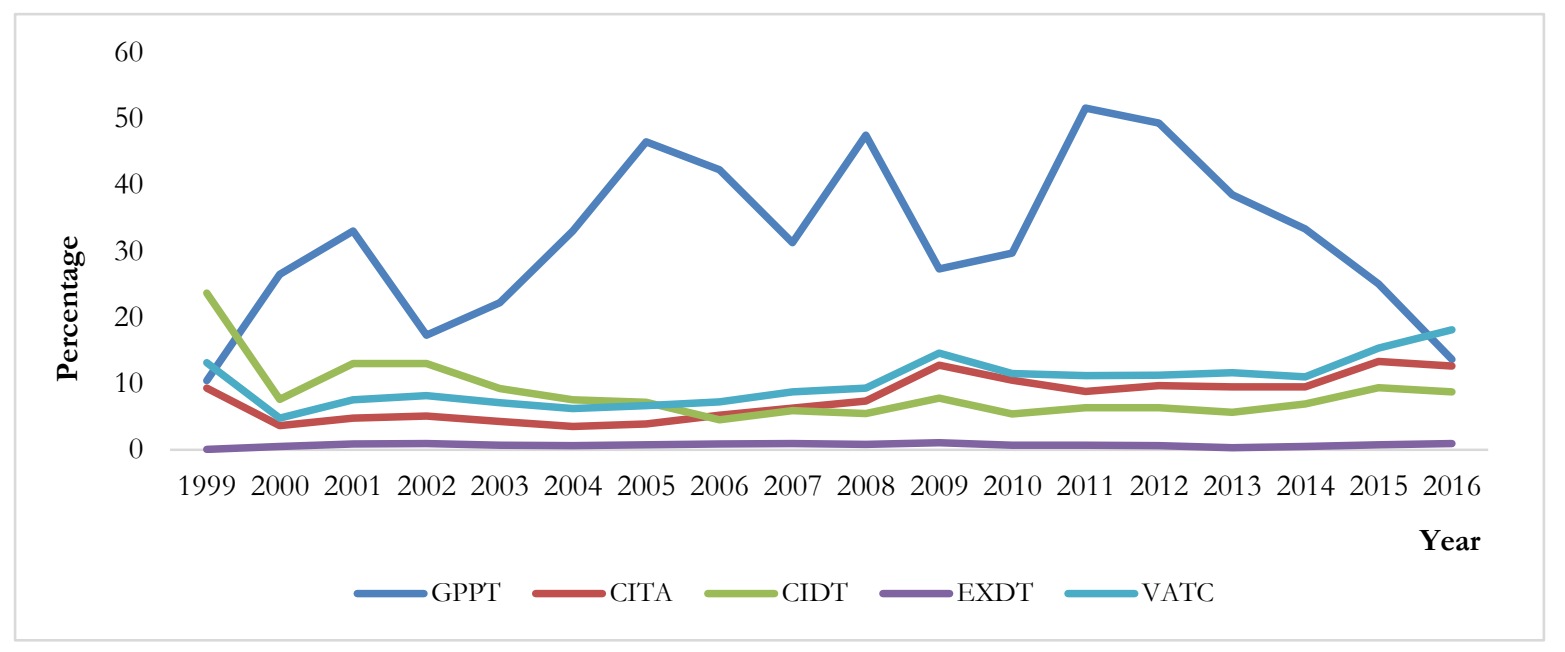

Figure 2. Share of tax component revenue to government revenue 1999-2006

Source. Computed by the Author.

\section{Relevant Literature}

\subsection{Theoretical Reviews}

Among the critical components of government revenue is a tax. The system employed to collect tax experiences different stages based on the process of economic development. At the initial stage of development processes, the use of direct tax exhibits a limited range because the majority of people living in rural areas practice subsistence farming for their livelihoods. Therefore, it is a very difficult to assess the tax. In addition, presumptions associated with wide margins of error is the basis for assessing the tax. Put differently, the degree of tax evasion and avoidance is high at this early stage.

Difficulties of collecting taxes also arise from the absence of skills and facilities for administration (Hinricks, 1966). The lack of industries at this period contributes to little or no revenue from indirect tax (such as excise tax). A sales tax system remains difficult to implement because of several retail outlets as well as a multiple-stage tax system (Musgrave, 1969). Also, the high relative share of self-employment poses an obstacle to the workability of the personal income tax. This implies that effective taxation is restricted to the wage income of civil servants and employees of large firms.

International trade sector serves as another source of government revenue during the early stage of development as export and import activities have been carried out. However, what government obtains from the export duties and customs duties are not stable due to the rapid fluctuations of primary commodities in the global market. This affects plan implementation in many less developed economies (Massell, Pearson, \& Fitch, 1972; Lim, 1972). Theoretically, as an economy develops and import substitution advances, there is the tendency of adjustment from import duties to excise duties on locally made products (Prest, 1972). Thus, it is possible to generate revenue internally rather than relied on the vagaries of foreign trade.

Similarly, Musgrave's theory of tax structure postulates that as development proceeds, the economy tends to shift from depending on revenue from indirect taxes to direct tax revenue as a result of the pecuniary/ financial nature of the economy.

As economic development improves the contribution of direct taxes to government revenue rises. Also, the scope of the sales tax would widen because output and income transactions would take place in the money market as the economy becomes more monetized. Personal income tax is effectively managed due to a rise in the share of employment in the industrial sector, but a fall in the dominance of the agricultural sector. According to Musgrave (1969), at this level, taxes may be imposed on individuals, expenditures or receipts, factor inputs or products etc. In addition, there would be a tendency to shift from indirect taxes to direct taxes. This development is associated with legal and institutional obstacles in which several expenditures are made or income received.

\subsection{Empirical Reviews}

Wong (2004) employed panel data of 105 Kansas counties to examine the fiscal influence of economic growth and development on local government revenue capacity between 1981 and 1997. His model incorporated 
variables such as tax capacity, county property tax rates, population, personal income etc. He found that tax capacity is significantly determined by population density, the general price level, and the presence of local retail sales taxes. However, Okech and Mburu (2011) employed the double-log model to investigate how tax revenue responds to changes in Kenyan national income between 1986 and 2009. Their results revealed that tax revenue was neither buoyant nor income-elastic despite reforms initiated in Kenya over the sample period.

Similarly, Muriithi (2013) examined the same relationship for the case of Kenyan economy but with the use of ANOVA technique for the sample period 1992 to 2011. The finding indicates that economic growth and import duty are inversely related while there is a positive relationship between income tax and economic growth. In addition, VAT positively affects the growth rate of the economy.

However, Omojolaibi and Egwaikhide (2013) analyzed the link between oil price and macroeconomic variables in some selected African countries (Algeria, Angola, Egypt, Libya and Nigeria) using panel data for the period 1990: q1-2010:q4. The results of panel vector autoregressive (PVAR) model indicated that gross investment responds more to fluctuations in oil prices than fiscal deficits, real GDP, and money supply. Also, it was found that gross investment serves as the main channel through which oil prices dynamics affect the macroeconomic performance of these economies. In the same vein, Oriakhi and Osemwengie (2013) investigated tax incentives and revenue productivity of tax system in Nigeria using ordinary least square for the period 1981 to 2009 . They concluded that the poor tax effect in the country in relation to the tax system is as a result of non-buoyancy and poor productivity of the total tax revenue.

Bassey, Edom, and Eyisi (2015) empirically assessed the efficiency of the tax system in Nigeria using annual data from 1970 to 2013. Their finding of multiple regression techniques shows the presence of a significant relation between economic activities and direct taxes (petroleum profit tax) on one hand, and between economic activities and indirect taxes (customs and excise duties) on the other hand. In addition, Jones, Ihendinihu and Nwaiwu (2015) examined the presence of a relationship between total revenue and economic growth in Nigeria. They utilized both OLS univariate method and the Error Correction Method in analyzing the relationship. Their result revealed the existence of both short and long run relationship between total revenue and economic growth in Nigeria. Also, it indicates that variations in the total revenue account for about 63.6 percent variations in the country real gross domestic product.

Of recent, Edeme, Nkalu, Azu and Nwachukwu (2016) estimated the link between tax revenue and gross domestic products from 1970 to 2013. With the aid of Bayesian technique, they found that the high growth rate of GDP does not lead to rapid growth of tax-GDP ratio over the past years.

\section{Analytical Framework and Methodology}

The study commences its analysis by investigating the productivity of federal government revenue in Nigeria with a special focus on tax revenue. This is implemented to determine the efficiency of tax administration system in the country. Historically, the structure of Nigerian economy plays a critical role in the pattern of tax revenue. Therefore even with a broad tax base, the budget will still be strained at least in the short to medium term.

Broadly, the buoyancy of a tax is estimated under the following assumed functional form:

$$
\text { RealTR }=A Y^{\beta_{1}} \varepsilon_{t}
$$

The log transformation of the equation is expressed as:

$$
\log \text { RealTR }=\log A+\beta_{1} \log Y+\varepsilon_{t}
$$

Where RealTR is real tax revenue, $\mathrm{A}$ is a constant, $\mathrm{Y}$ is the tax base (which is GDP) and $\varepsilon_{t}$ is an error term. The parameter $\beta_{1}$ denotes the direct measure of buoyancy.

\subsection{Hypothesis Development}

The study tests the following hypothesis:

Hypothesis: The level of income significantly influences the sources of government tax revenue. As its magnitude gets larger, so its impact does.

This hypothesis is an application of the economic theory of taxation. The reviewed studies have identified a number of factors that indicate a strong link with revenue performance. One such factor is per capita income. They found that higher per capita income is not only an indicator of a large tax base but also a proxy for a higher level of economic development, implying a higher capacity to mobilize revenue. Also, this factor (per capita income) is supported on the basis of Wagner's law that states that the demand for government services is an elastic function of income. This implies that an increase in GDP leads to a rise in demand for government 
services, necessary for raising government revenue to execute these rising expenditures.

In the light of the above, two other fundamental hypotheses are obviously identified. First, the level of development has a strong influence on fiscal revenue. Second, the significance of government trade revenue reduces the level of development. Therefore, this study develops two models to test these hypotheses. The first model is total revenue equation that functionally relates to the value of merchandize exports and imports as well as the gross domestic product. The model is generally written as:

$$
\text { GovRev }_{t}=\beta_{0}+\beta_{1} E x_{t}+\beta_{2} \operatorname{Im}_{t}+\beta_{3} G D P_{t}+\varepsilon_{t}
$$

Where it is expected that

$$
\frac{d G o v R e v}{d E x}>0 ; \quad \frac{d G o v R e v}{d I m}>0 \quad \frac{d G o v R e v}{d G D P}>0
$$

GovRev is total federally collected revenue, GDP is the gross domestic products, Ex is the value of export and Im is the value of import, and $\varepsilon$ and $t$ represent the error term and time (month) respectively.

The second model links the tax components' revenue to the level of economic development as well as import and export. The model is expressed as:

$$
\begin{gathered}
\text { TCGRev }_{t}=\beta_{0}+\beta_{1} E x_{t}+\beta_{2} \operatorname{Im}_{t}+\beta_{3} G D P_{t}+\varepsilon_{t} \\
\frac{d T C G R e v}{d G D P}>0 \quad \frac{d T C G v R e v}{d E x}>0 ; \quad \frac{d T C G R e v}{d I m}>0
\end{gathered}
$$

Data Source: The data for these models are mainly sourced from the Central Bank of Nigeria (CBN)'s Statistical Bulletins and the National Bureau of Statistics (NBS)

\section{Results and Discussion}

\subsection{Data Descriptions}

This study examines the influence of economic growth on the total government revenue and the tax revenue components in Nigeria over the period spanning from January 1999 to May 2016. The availability of comprehensive data dictates the choice of the sample period.

The government revenues, as well as tax revenue, are quoted in Nigerian currency. The revenues are expressed in real terms by deflating them by the Nigerian consumer price index (CPI). Data on real gross domestic products (GDP), export and import are also expressed in the Nigerian currency. However, import and export are transformed to real terms by deflating with Nigerian consumer price index (CPI). These data are obtained from Central Bank of Nigeria (CBN) mostly denominated in nominal terms.

\subsection{Result of Descriptive Statistics}

Table 2 provides a descriptive analysis for the concerned variables in levels. It is important to observe that the mean of monthly gross domestic product accounts for the highest level over the investigation period. In addition, the volatility of GDP as captured by standard deviation is highest with about N15.6 billion.

Table 2. Descriptive statistics

\begin{tabular}{cccccccccc}
\hline Statistics & gdp (N'bn) & realcidt & realcita & realexdt & realexpt & realgppt & realimpt & realtrev & realvatc \\
\hline Mean & 53.64 & $2.53 \mathrm{E}+08$ & $2.46 \mathrm{E}+08$ & 24058107 & 7912.81 & $1.23 \mathrm{E}+09$ & 3315.942 & $3.46 \mathrm{E}+09$ & $3.14 \mathrm{E}+08$ \\
Median & 51.22 & $2.49 \mathrm{E}+08$ & $2.18 \mathrm{E}+08$ & 24341020 & 7715.95 & $1.16 \mathrm{E}+09$ & 3118.731 & $3.62 \mathrm{E}+09$ & $2.96 \mathrm{E}+08$ \\
Maximum & 80.16 & $4.24 \mathrm{E}+08$ & $1.17 \mathrm{E}+09$ & 63241739 & 21022.87 & $3.05 \mathrm{E}+09$ & 13142.29 & $5.56 \mathrm{E}+09$ & $6.07 \mathrm{E}+08$ \\
Minimum & 32.03 & $1.31 \mathrm{E}+08$ & 60264026 & 29174.30 & 1212.55 & -9899788. & 534.1300 & $4.50 \mathrm{E}+08$ & 97568974 \\
Std. Dev. & 15.57 & 59074973 & $1.59 \mathrm{E}+08$ & 11702428 & 3431.63 & $6.52 \mathrm{E}+08$ & 1980.468 & $8.71 \mathrm{E}+08$ & $1.20 \mathrm{E}+08$ \\
Skewness & 0.32 & 0.644952 & 2.406677 & 0.281346 & 1.10 & 0.315302 & 2.180408 & -0.921836 & 0.050485 \\
Kurtosis & 1.80 & 3.397183 & 12.78975 & 3.721330 & 4.97 & 2.530681 & 9.672338 & 4.999042 & 1.738697 \\
JB & 14.92 & 14.57284 & 952.0603 & 6.695515 & 70.17 & 4.943367 & 508.2945 & 59.16236 & 12.80865 \\
Probability & 0.00 & 0.000685 & 0.000000 & 0.035163 & 0.00 & 0.084443 & 0.000000 & 0.000000 & 0.001654 \\
Sum & 10298.71 & $4.85 \mathrm{E}+10$ & $4.72 \mathrm{E}+10$ & $4.62 \mathrm{E}+09$ & 1519259. & $2.36 \mathrm{E}+11$ & 636660.9 & $6.63 \mathrm{E}+11$ & $6.02 \mathrm{E}+10$ \\
Sum Sq. Dev. & 46310.21 & $6.67 \mathrm{E}+17$ & $4.83 \mathrm{E}+18$ & $2.62 \mathrm{E}+16$ & $2.25 \mathrm{E}+09$ & $8.12 \mathrm{E}+19$ & $7.49 \mathrm{E}+08$ & $1.45 \mathrm{E}+20$ & $2.74 \mathrm{E}+18$ \\
Obs. & 192 & 192 & 192 & 192 & 192 & 192 & 192 & 192 & 192 \\
\hline
\end{tabular}

Source. Compiled by author. 


\subsection{Correlation Matrices}

As reported in Table 3, the correlation coefficients show that total revenue as well as tax revenue components (with the exception of customs import duty tax) and gross domestic products (GDP) are linearly and positively associated. Any shock to one of the variables might influence the others. The value added tax is highly and positively related to the GDP.

Similarly, real export (realexpt) has a linear and positive relationship with the total government revenue and tax component revenue, but a negative link with custom import duty tax (realcidt). The relationship of real import value to the government revenue and tax components revenue follows a similar pattern as observed in the real export case. However, the simple correlation coefficients do not capture causality. Employing more advanced approaches is very important in examining the presence and direction of causality.

Table 3. Correlation coefficients

\begin{tabular}{|c|c|c|c|c|c|c|c|c|c|}
\hline Variable & gdp & realcidt & realcita & realexdt & realexpt & realgppt & realimpt & realtrev & realvatc \\
\hline gdp & 1.0000 & -0.2657 & 0.7049 & 0.1458 & 0.5857 & 0.5198 & 0.5242 & 0.5409 & 0.8903 \\
\hline realcidt & & 1.0000 & -0.1587 & -0.0141 & -0.2165 & -0.1801 & -0.1560 & -0.1242 & -0.1847 \\
\hline realcita & & & 1.0000 & 0.1477 & 0.4244 & 0.3843 & 0.4370 & 0.5002 & 0.6953 \\
\hline realexdt & & & & 1.0000 & 0.1602 & 0.3185 & 0.3373 & 0.3448 & 0.3195 \\
\hline realexpt & & & & & 1.0000 & 0.6590 & 0.2673 & 0.5806 & 0.5388 \\
\hline realgppt & & & & & & 1.0000 & 0.2870 & 0.6991 & 0.4957 \\
\hline realimpt & & & & & & & 1.0000 & 0.3227 & 0.6078 \\
\hline realtrev & & & & & & & & 1.0000 & 0.5542 \\
\hline realvatc & & & & & & & & & 1.0000 \\
\hline
\end{tabular}

Source. Author's computation.

\subsection{Granger Causality Results}

The results reveal a uni-directional granger causality running from real GDP to real company income tax; from real GDP to real gross petroleum profit tax; from real GDP to real import; from real GDP to real value-added tax. Also, real custom import duty granger causes real company income tax but real company income tax does not granger cause real custom import duty. A uni-directional granger causality is also established among the following: from real government revenue to real custom import duty; from real custom import to real value added tax etc. Whereas bi-directional granger causality is found between real import and company income tax; between value-added tax and real import (See Table B.1).

\subsection{Econometric Framework}

This section provides the econometric framework utilized to investigate the cointegrating relationship between the concerned variables as well as analyze the long-run causality from real GDP to government revenue and their tax revenue components. The short-run influences of real GDP, real export and real import on tax revenue components are also examined.

\subsubsection{Unit root test}

The study observes the time series nature of the variables in the models by employing both the Augmented Dickey-Fuller (ADF) test (Dickey \& Fuller, 1979) and the Phillip and Perron (PP) test.

The findings of unit root tests are presented in Table 2. The result of unit root tests with none scenario shows that all variables are stationary at first difference based on ADF and PP approach, but GDP is stationary at first difference based on PP test. For the case of only constant scenario, both ADF and PP tests indicate that all variables except GDP and company income tax are stationary at a level based on 10 percent level of significance. However, for the case of constant and trend scenario, only real GDP, real company income tax, and excise duty tax are stationary by taking the first difference of each variable at 1 percent level of significance. 
Table 4. Unit root test

\begin{tabular}{|c|c|c|c|c|c|}
\hline \multirow{2}{*}{$\begin{array}{l}\text { Series } \\
\text { None }\end{array}$} & \multicolumn{3}{|c|}{$\mathrm{ADF}$} & \multicolumn{2}{|c|}{ PP } \\
\hline & Level & 1st Difference & 2nd Difference & Level & 1st Difference \\
\hline LNGDP & 0.933645 & -1.22421 & $-15.4893 * * *$ & 9.670994 & $-1.835373 *$ \\
\hline LNREALCIDT & 0.239582 & $-16.9348 * * *$ & - & 0.472581 & $-31.8319 * * *$ \\
\hline LNREALCITA & 3.256279 & $-10.86265^{* * *}$ & & 1.136473 & $-34.2033^{* * *}$ \\
\hline LNREALEXDT & 0.928506 & $-12.5880 * * *$ & - & 0.853998 & $-23.0237 * * *$ \\
\hline LNREALEXPT & 0.213739 & $-11.7529 * * *$ & - & 0.030236 & $-25.1275^{* * *}$ \\
\hline LNREALGPPT & 0.833670 & $-19.0413 * * *$ & - & 0.934833 & $-19.0510^{* * *}$ \\
\hline LNREALIMPT & 0.092674 & $-26.9780 * * *$ & - & 0.816629 & $-45.6789 * * *$ \\
\hline LNREALTREV & 1.090791 & $-17.5659 * * *$ & - & 0.982407 & $-17.4686^{* * * *}$ \\
\hline LNREALVATC & 1.435164 & $-20.20122 * * *$ & - & 2.231046 & $-42.2441 * * *$ \\
\hline \multicolumn{6}{|l|}{ Constant Only } \\
\hline LNGDP & -1.574818 & -1.614391 & $-15.4767 * * *$ & -1.08259 & $-5.831756^{* * *}$ \\
\hline LNREALCIDT & $-3.342808 * *$ & - & - & $-8.03077 * * *$ & - \\
\hline LNREALCITA & -1.200598 & $-11.64801 * * *$ & - & $-3.77277 * * *$ & - \\
\hline LNREALEXDT & $-7.159289 * * *$ & - & - & $-7.39158^{* * *}$ & - \\
\hline LNREALEXPT & $-3.157114^{*}$ & - & - & $-5.53378^{* * *}$ & - \\
\hline LNREALGPPT & $-7.029057 * * *$ & - & - & $-8.27374^{* * *}$ & - \\
\hline LNREALIMPT & $-2.845834^{*}$ & - & - & $-5.86344 * * *$ & - \\
\hline LNREALTREV & $-6.523824 * * *$ & - & - & $-6.11614^{* *}$ & - \\
\hline LNREALVATC & -1.959442 & $-20.31851^{* * *}$ & - & $-2.9413^{* *}$ & - \\
\hline \multicolumn{6}{|l|}{ Constant \& Trend } \\
\hline LNGDP & -0.653489 & -1.839121 & $-12.1648 * * *$ & -0.34863 & $-6.059121^{* * *}$ \\
\hline LNREALCIDT & $-3.555665^{* *}$ & - & - & $-8.34276^{* * * *}$ & - \\
\hline LNREALCITA & -0.380051 & $-11.71156^{* * *}$ & - & $-8.63963^{* * *}$ & - \\
\hline LNREALEXDT & -6.713231 & $-12.9767 * * *$ & - & $-7.10703 * * *$ & - \\
\hline LNREALEXPT & $-4.238551 * * *$ & - & - & $-7.17266^{* * *}$ & - \\
\hline LNREALGPPT & $-7.313115^{* * * *}$ & - & - & $-8.68233^{* * *}$ & - \\
\hline LNREALIMPT & $-4.332571 * * *$ & - & - & $-9.533 * * *$ & - \\
\hline LNREALTREV & $-5.937773 * * *$ & - & - & $-5.95686^{* * *}$ & - \\
\hline LNREALVATC & -2.837498 & $-20.357 * * *$ & - & $-10.873^{* * *}$ & - \\
\hline
\end{tabular}

Note. $* * *$ indicates significant at $1 \%$, ** indicates significant at $5 \%$ and $*$ indicates significant at $10 \%$.

\subsubsection{ARDL Cointegration Approach}

Based on the outcomes of the unit root testing, the study examines the cointegration relationship between the variables using Autoregressive Distributed Lag (ARDL) approach. This method is applicable for time series data that are integrated into different orders (a mixture of I (0) and I (1)). Therefore, the approach is even used without checking the integration order of the variables since it addresses the issues arising from non-stationary time series. In addition, it simultaneously estimates the short-run and long-run influence of the explanatory variables on the dependent variable. Among the features of the ADRL technique is the effectiveness in analyzing small sample size compared to other methods.

The initial task in the analysis is to determine the Wald F-statistics for the combined significance of the coefficients. The F-statistics are placed against the tabulated critical values. There is the presence of cointegration if the Wald F-statistics are above the upper bound critical value. On the other hand, cointegration does not exist if the Wald F-statistics are below the lower bound critical value. Inconclusive decision occurs if the Wald F-statistics lies between the upper and lower bound critical values (Al-Mulali, Saboori, \& Ozturk, 2015).

To utilize the ADRL methodology, the error correction models are expressed as follows:

$$
\begin{gathered}
\Delta L N R G P P T_{t}=\alpha_{0}+\sum_{i=1}^{n 1} \alpha_{1 i} \Delta L N R G P P T_{t-i}+\sum_{i=0}^{n 2} \alpha_{2 i} \Delta L N R G D P_{t-i}+\sum_{i=0}^{n 3} \alpha_{3 i} \Delta L N R E X P T_{t-i}+ \\
\sum_{i=1}^{n 4} \alpha_{4 i} \Delta L N R I M P T_{t-i}+\beta_{0} L N R G P P T_{t-1}+\beta_{1} L N R G D P_{t-1}+\beta_{2} L N R E X P T_{t-1}+\beta_{3} L N R I M P T_{t-1}+u_{t} \\
\Delta L N R C I D T_{t}=\partial_{0}+\sum_{i=1}^{n 1} \partial_{1 i} \Delta L N R C I D T_{t-i}+\sum_{i=0}^{n 2} \partial_{2 i} \Delta L N R G D P_{t-i}+\sum_{i=0}^{n 3} \partial_{3 i} \Delta L N R E X P T_{t-i}+\sum_{i=1}^{n 4} \partial_{4 i} \Delta L N R I M P T_{t-i}+
\end{gathered}
$$




$$
\begin{aligned}
& \pi_{0} L_{N R C I D T_{t-1}}+\pi_{1} L_{N R G D P_{t-1}}+\pi_{2} L_{N R E X P T_{t-1}}+\pi_{3} L_{N R I M P T_{t-1}}+\varepsilon_{t} \\
& \vartheta_{0} \text { LNRCITA }_{t-1}+\vartheta_{1} L_{N R G D P_{t-1}}+\vartheta_{2} \text { LNREXPT }_{t-1}+\vartheta_{3} L_{N R I M P T_{t-1}}+\epsilon_{t} \\
& \Delta L N R V A T C_{t}=\delta_{0}+\sum_{i=1}^{n 1} \delta_{1 i} \Delta L N R V A T C_{t-i}+\sum_{i=0}^{n 2} \delta_{2 i} \Delta L N R G D P_{t-i}+\sum_{i=0}^{n 3} \delta_{3 i} \Delta L N R E X P T_{t-i}+\sum_{i=1}^{n 4} \delta_{4 i} \Delta L N R I M P T_{t-i}+ \\
& \tau_{0} L_{N R V A T C} C_{t-1}+\tau_{1} L N R G D P_{t-1}+\tau_{2} L N R E X P T_{t-1}+\tau_{3} L N R I M P T_{t-1}+\varphi_{t} \\
& \triangle L N R E X D T_{t}=\rho_{0}+\sum_{i=1}^{n 1} \rho_{1 i} \Delta L N R E X D T_{t-i}+\sum_{i=0}^{n 2} \rho_{2 i} \Delta L N R G D P_{t-i}+\sum_{i=0}^{n 3} \rho_{3 i} \Delta L N R E X P T_{t-i}+ \\
& \sum_{i=1}^{n 4} \rho_{4 i} \Delta L N R I M P T_{t-i}+\sigma_{0} L N R E X D T_{t-1}+\sigma_{1} L N R G D P_{t-1}+\sigma_{2} L N R E X P T_{t-1}+\sigma_{3} L_{N R I M P T_{t-1}}+\omega_{t} \\
& \Delta L N R T R E V_{t}=\theta_{0}+\sum_{i=1}^{n 1} \theta_{1 i} \Delta L N R T R E V_{t-i}+\sum_{i=0}^{n 2} \theta_{2 i} \Delta L N R G D P_{t-i}+\sum_{i=0}^{n 3} \theta_{3 i} \Delta L N R E X P T_{t-i}+\sum_{i=1}^{n 4} \theta_{4 i} \Delta \operatorname{LNRIMPT}_{t-i}+ \\
& \chi_{0} L_{N R T R E V_{t-1}}+\chi_{1} L N R G D P_{t-1}+\chi_{2} L_{N R E X P T_{t-1}}+\chi_{3} L N R I M P T_{t-1}+\phi_{t}
\end{aligned}
$$

The $\alpha_{0}, \partial_{0}, \gamma_{0}, \delta_{0}, \rho_{0}$ and $\theta_{0}$ are the drift components in equations 5-10. $u_{t}, \varepsilon_{t}, \epsilon_{t}, \varphi_{t}, \omega_{t}$ and $\phi_{t}$ are the white noise in equations 5-10. $\alpha_{1}-\alpha_{4} ; \partial_{1}-\partial_{4}, \gamma_{1}-\gamma_{4}, \delta_{1}-\delta_{4}, \rho_{1}-\rho_{4}$ and $\theta_{1}-\theta_{4}$ denote the error correction dynamics while $\beta_{0}-\beta_{3}, \pi_{0}-\pi_{3}, \vartheta_{0}-\vartheta_{3}, \tau_{0}-\tau_{3}, \sigma_{0}-\sigma_{3}$, and $\chi_{0}-\chi_{3}$ correspond to the long run relationship among variables.

The ARDL technique in relation to the Wald-F-statistics is used to investigate the presence of cointegration between the variables. The null hypotheses of no-cointegration in equations:

$H_{0 L N R G P P T}: \beta_{0}=\beta_{1}=\beta_{2}=\beta_{3}=0 ; H_{0 L N R C I D T}: \pi_{0}=\pi_{1}=\pi_{2}=\pi_{3}=0$

$H_{\text {OLNRCITA }}: \vartheta_{0}=\vartheta_{1}=\vartheta_{2}=\vartheta_{3}=0 ; H_{0 L N R V A T C}: \vartheta_{0}=\vartheta_{1}=\vartheta_{2}=\vartheta_{3}=0$

$H_{0 L N R E X D T}: \tau_{0}=\tau_{1}=\tau_{2}=\tau_{3}=0 ; H_{0 L N R T E V}: \sigma_{0}=\sigma_{1}=\sigma_{2}=\sigma_{3}=0$ respectively.

These above-specified equations are tested against the following alternatives:

$H_{1 L N R G P P T}: \beta_{0} \neq \beta_{1} \neq \beta_{2} \neq \beta_{3} \neq 0 ; H_{1 L N R C I D T}: \pi_{0} \neq \pi_{1} \neq \pi_{2} \neq \pi_{3} \neq 0$

$H_{1 L N R C I T A}: \vartheta_{0} \neq \vartheta_{1} \neq \vartheta_{2} \neq \vartheta_{3} \neq 0 ; H_{1 L N R V A T C}: \tau_{0} \neq \tau_{1} \neq \tau_{2} \neq \tau_{3} \neq 0$

$H_{1 L N R E X D T}: \sigma_{0} \neq \sigma_{1} \neq \sigma_{2} \neq \sigma_{3} \neq 0 ; H_{1 L N R T R E V}: \chi_{0} \neq \chi_{1} \neq \chi_{2} \neq \chi_{3} \neq 0$ respectively.

In line with the modeling technique described earlier, the study proceeds for testing the long run equilibrium among the concerned variables with the use of Autoregressive Distributed Lag (ARDL) approach.

$$
\begin{aligned}
& L N R G P P T_{t}=\alpha_{01}+\sum_{i=1}^{4} \alpha_{i 1} L N R G P P T_{t-i}+\alpha_{51} L N R I M P T_{t}+\alpha_{61} L N G D P_{t}+\alpha_{71} L N R E X P T_{t}+u_{t 1} \\
& \text { LNREALCITA }_{t}=\alpha_{02}+\sum_{i=1}^{4} \alpha_{i 2} \text { LNREALCITA }_{t-i}+\alpha_{52} \text { LNRIMPT }_{t}+\alpha_{62} \text { LNREXPT }_{t}+\alpha_{72}{ }_{\text {LNGDP }}+u_{t 2} \\
& \text { LNRCIDT }_{t}=\alpha_{03}+\sum_{i=1}^{4} \alpha_{i 3} L_{N R C I D T} T_{t-i}+\alpha_{53} L_{N R I M P T_{t}}+\alpha_{63} L_{N R E X P T_{t}}+\alpha_{73} L N G D P_{t}+u_{t 3} \\
& \text { LNRVATC }_{t}=\alpha_{04}+\sum_{i=1}^{4} \alpha_{i 4} L N R V A T C_{t-i}+\alpha_{54} L N R I M P T_{t}+\alpha_{64} L N E X P T_{t}+\alpha_{74} L N G D P_{t}+u_{t 4} \\
& \text { LNREALTREV }_{t}=\alpha_{05}+\sum_{i=1}^{4} \alpha_{i 5} L N R E A L T R E V_{t-i}+\alpha_{55} L N R I M P T_{t}+\alpha_{65} L N R E X P T_{t}+\alpha_{75} L N G D P_{t}+u_{t 5} \\
& L N R E A L E X D T_{t}=\alpha_{06}+\sum_{i=1}^{4} \alpha_{i 6} L N R E A L E X D T_{t-i}+\alpha_{56} L N R I M P T_{t}+\alpha_{66} L N G D P_{t}+\alpha_{76} L N R E X P T_{t}+u_{t 6}
\end{aligned}
$$

The estimation of ARDL model is presented in Table A.1-A.3, and their outcomes are subjected to a bound test in order to investigate the presence of cointegration. The results of the bound tests presented in Table 5 reveal the rejection of the null of no cointegration for all the models except LNRCIDT and LNRVATC models. This indicates the long run equilibrium among the variables, but in the short run, the series may diverge from one another. In addition, the significant F-statistics supports the cointegration between the variables.

Table 5. Result of bound tests

\begin{tabular}{lccc}
\hline VARIABLE & F-Statistic & I0 Bound & I1 Bound \\
\hline LNRCIDT & 3.1433 & 2.79 & 3.67 \\
LNREALCITA & 7.3669 & 2.79 & 3.67 \\
LNREALTREV & 10.1000 & 2.79 & 3.67 \\
LNRVATC & 3.0140 & 2.79 & 3.67 \\
LNRGPPT & 7.9011 & 2.79 & 3.67 \\
LNREXDT & 12.7165 & 2.79 & 3.67 \\
\hline
\end{tabular}


Having established the presence of cointegration, the study examines the dynamic influence of explanatory variables on the explained variable using the Vector Error Correction Model (VECM).

\subsubsection{Results of Vector Error Correction Model (VECM)}

Table 6 below presents the estimation results of the dynamic model of total revenue and tax component revenues. The analysis of the independent variables indicates that real GDP has a positive and significant impact on real company income tax and real excise duty tax. The positive impact of real GDP on excise duty tax is consistent with the theoretical expectation as the excise duty is one form of indirect tax sources. This supports the theoretical view of Hinricks (1966).

The long-run influence of real import on real company income tax, value added tax, gross petroleum profit tax, and real excise duty tax are statistically significant and negative with coefficients of $-0.995,-0.863,-0.688$, and -1.769 respectively. However, real import has an insignificant effect on the customs duty and total revenue.

Real export exhibits a significant long-term impact on real custom import duty tax, real total government revenue and real gross petroleum profit tax with the coefficients of $-0.508,-0.333$, and -1.372 respectively. On the other hand, real gross domestic product has a statistically significant and positive influence on real company income tax and real excise duty tax with long-run elastic coefficients of about 60.4 and 2.3 respectively. The long-run effect of real GDP on real custom import duty tax, real value-added tax, real total revenue and real gross petroleum profit tax is statistically insignificant and positive but negative for the case of total government revenue with -2.51 . This effect is similar with the result of Oriakhi and Osemwengie (2013). In terms of magnitude, the income elasticity of real company income tax is relatively large compared to other sources of tax revenue. The table also reveals that level of economic development mainly influences the level of direct tax revenue through company income tax, and influences the level of indirect tax revenue mainly through excise duty tax. However, the results of short run estimation indicate that only the one- year lag and the two- year lag of the dependent variables have a significant impact on the dependent variable in each of the models.

The error correction term (ECT) that indicates the adjustment speed of the variables towards the long-run equilibrium has a statistically negative coefficient in each of the models. In the CITA model, the coefficient of the error correction term is about 23 percent, implying if there is any disequilibrium in the economy, it will take about 5 months for the equilibrium to be restored. However, the speed of adjustment (-0.33) in TREV model is higher compared to other models, suggesting that within three months a situation will be normalized if there is any shock. In the total revenue model, about 33 percent deviations from the long-run trajectory are corrected per month. The real GDP is a major driver of tax revenue in the country. Total revenue tends to adjust faster compared to other tax revenue sources during the disequilibrium situation.

With respect to the impact of real export, the results reveal that it produces a positive and significant influence on real total government revenue and real gross petroleum profit tax revenue. This implies that growth in real export boosts the capacity of the economy to increase government revenue.

Table 6. Long run and short run results

\begin{tabular}{lcccccc}
\hline Long run coefficient estimates & LNREALCITA & LNRCIDT & LNRVATC & LNREALTREV & LNRGPPT & LNREALEXDT \\
\hline \multirow{2}{*}{ LNREXPT (-1) } & -0.2117 & 0.5083 & -0.0806 & -0.3327 & -1.3716 & LNREALEXDT(-1) \\
& $(-1.2182)$ & $(3.6655)$ & $(-0.6418)$ & $(-4.3314)$ & $(-5.1191)$ & -1.769188 \\
LNRIMPT (-1) & -0.9952 & -0.1460 & -0.8630 & -0.1010 & -0.6883 & $(-7.0677)$ \\
& $(-7.0165)$ & $(-1.2876)$ & $(-8.4274)$ & $(-1.5915)$ & $(-2.6146)$ & 2.3846 \\
GRGDP (-1) & 60.3626 & 32.1871 & 36.9999 & -2.5072 & 1.0933 & $(4.5004)$ \\
Constant & $(2.0497)$ & $(1.3689)$ & $(1.7380)$ & $(-0.1917)$ & $(1.9960)$ & -1.3600 \\
Short run coefficient estimates & -9.6430 & -22.8374 & 12.0760 & -18.1650 & & \\
& & & & & & -0.45888 \\
$\Delta$ Dependent var. (-1) & -0.3508 & -0.4519 & -0.7816 & -0.1271 & -0.1970 & $(-7.1814)$ \\
& $(-4.3490)$ & $(-6.0478)$ & $(-11.2554)$ & $(-1.8456)$ & $(-2.8764)$ & -0.1746 \\
$\Delta$ Dependent var. (-2) & -0.0841 & -0.3235 & -0.5043 & 0.0299 & 0.0244 & $(-2.7509)$ \\
& $(-1.1200)$ & $(-4.6661)$ & $(-7.5917)$ & $(0.4519)$ & $(0.3873)$ & 0.0404 \\
$\Delta$ LNREXPT (-1) & 0.0659 & 0.0666 & -0.0446 & -0.0684 & -0.2128 & $(0.3741)$ \\
$\Delta$ LNREXPT (-2) & $(0.9088)$ & $(1.3530)$ & $(-1.2544)$ & $(-1.8265)$ & $(-1.9758)$ & -0.0586 \\
\hline
\end{tabular}




\begin{tabular}{lcccccc}
\hline \multirow{2}{*}{$\Delta$ LNRIMPT (-1) } & -0.1326 & -0.0339 & -0.0328 & 0.0041 & -0.1170 & -0.3995 \\
& $(-1.7464)$ & $(-0.8240)$ & $(-0.8137)$ & $(0.1323)$ & $(-1.3794)$ & $(-3.8657)$ \\
$\Delta$ LNRIMPT (-2) & -0.0261 & 0.0036 & 0.0451 & 0.0370 & -0.1553 & -0.0610 \\
& $(-0.3907)$ & $(0.0888)$ & $(1.3340)$ & $(1.1755)$ & $(-1.8974)$ & $(-0.6392)$ \\
$\Delta$ GRGDP (-1) & 10.2819 & 10.1923 & 7.4126 & 1.3188 & -19.7126 & 6.4451 \\
& $(0.8755)$ & $(1.4133)$ & $(1.3240)$ & $(0.2406)$ & $(-1.4041)$ & $(0.4114)$ \\
$\Delta$ GRGDP (-2) & 1.8100 & 11.6357 & 8.3335 & 1.5222 & 10.1955 & -31.4919 \\
& $(0.1580)$ & $(1.6461)$ & $(1.5159)$ & $(0.2800)$ & $(0.7054)$ & $(-1.9478)$ \\
Error & -0.2307 & -0.2224 & -0.0867 & -0.3301 & -0.2993 & -0.3153 \\
& $(-3.7995)$ & $(-4.0011)$ & $(-2.0192)$ & $(-6.8413)$ & $(-6.5813)$ & $(-7.571)$ \\
Constant & 0.0087 & 0.0025 & 0.0148 & 0.0096 & 0.0755 & 0.1660 \\
\hline
\end{tabular}

Note. T-statistics is in parenthesis.

Source. Author's computation.

\section{Conclusion and Policy Implications}

This study sets out to examine the dynamics of government tax revenue in Nigeria due to the recent needs for government to expand its tax revenue base. No previous study as far as the author's knowledge is concerned has attempted to examine the linkage between the level of government and tax component revenue in Nigeria using the high frequency of data. The monthly data spanning from 1999 to 2016 were utilized to estimate vector error correction models (VECM).

The results reveal a uni-directional granger causality running from real GDP to real company income tax; from real GDP to real gross petroleum profit tax; from real GDP to real import; from real GDP to real value-added tax. Also, real custom import duty granger causes real company income tax but real company income tax does not granger cause real custom import duty. A uni-directional granger causality is also established among the following: from real government revenue to real custom import duty; from real custom import to real value added tax etc. Whereas bi-directional granger causality is found between real import and company income tax; between value-added tax and real import (See Appendix B.1).

The result of total government revenue model indicates that real GDP does not influence the total revenue in both short-run and long-run scenarios. In the short run, real total government revenues are significantly affected by the lag-year of itself. However, the real GDP significantly influences the direct sources of government tax revenues through company income tax and significantly affects the indirect sources of government tax revenues through excise duty tax. Thus, their relationship is highly elastic.

All dependent variables are mainly influenced by a lag-year of themselves in the short run. In addition, the speed of adjustment ranges from 0.09 to 0.33 in absolute term. The lowest speed of adjustment is indicated in the value-added model while the highest is found in the total revenue model.

With pointed respect to policy implications on government revenue as well as the sources of tax revenues, a causal link running from real GDP to real company income tax implies that improving real GDP through strong domestic economic diversification, for instance, will lead to an increase in real company income tax revenues. Also, any improvement in real GDP will boost the government revenues generated from excise duty tax in the long run.

The short run results suggest that government revenue can be enhanced through taxation by addressing the factors that hinder the optimal realization of tax revenue in the country as indicated earlier. This can be achieved through expanding the tax base directly and indirectly, and then spending these revenues in facilitating the economic activities through the provision of enabling economic environment. In the light of this, there is a need to promote productivity of tax revenues through expanding tax base as well as eliminating corruption and inefficiency in the tax system.

\section{References}

Abiola, J. (2012). Impact of Tax Administration on Government Revenue in a Developing Economy - A Case Study of Nigeria. International Journal of Business and Social Science, 3(8), 99-113.

Acquah, J., \& Ojong, N. (2014). Tax revenue allocation and its effects on consumption (VAT): A study of Calabar Municipal Council, Cross River State. Archives of Applied Science Research, 6(1), 199-208.

Ayinde, K., Kuranga, J., \& Lukman, A. F. (2015). Modeling Nigerian Government Expenditure, Revenue and 
Economic Growth: Co-Integration, Error Correction Mechanism And Combined Estimators Analysis Approach. Asian Economic and Financial Review, 5(6), 858-867. http://dx.doi.org/10.18488/journal.aefr/2015.5.6/102.6.858.867

Bassey, B. E., Edom, G. O., \& Adanma, E. S. (2015). Empirical Assessment of the Efficiency of the Nigerian Tax System. Research Journal of Finance and Accounting, 6(14), 27-37.

Egwaikhide, F. O. (1988). Analysis of Structural Shift of Government Revenue in Nigeria, 1960-1982. The Nigerian Journal of Economic and Social Studies, 30(2).

Hinricks, H. (1966). A General Theory of Tax Structure Change during Economic Development. Harvard Law School, Cambridge, Massachusetts.

Jegede, C. A. (2014). Econometric Analysis of the Effectiveness of Public Revenue in Economic Growth in Developing Countries: An Examination of Nigerian Economy. International Journal of Economics and Finance, 6(8), 187-196. http://doi.org/10.5539/ijef.v6n8p187

Jones, E., Ihendinihu, J. U., \& Nwaiwu, J. N. (2015). Total Revenue And Economic Growth In Nigeria: Empirical Evidence. Journal of Emerging Trends in Economics and Management Sciences, 6(1), 40-46.

Lukpata, V. I. (2013). Revenue Allocation Formulae in Nigeria: A Continuous Search. International Journal of Public Administration and Management Research, 2(1), 32-38.

Massell, B. F., Pearson, S. R., \& Fitch, J. B. (1972). Foreign exchange and economic development: An empirical study of selected Latin American Countries. Review of Economics and Statistics, 208-212. http://dx.doi.org/10.2307/1926287

Musa, Y., Usman, U., \& Zoramawa, A. B. (2014). Relationship between Money Supply and Government Revenues in Nigeria. CBN Journal of Applied Statistics, 5(2), 117-136.

Musgrave, R. A. (1969). Fiscal Systems. New Haven: Yale University Press.

Ogbonna, G. N., \& Ebimobowei, A. (2012). Impact of Tax Reforms and Economic Growth of Nigeria: A Time Series Analysis. Current Research Journal of Social Sciences, 4(1), 62-68.

Okech, T. C., \& Mburu, P. G. (2011). Analysis Of Responsiveness Of Tax Revenue To Changes in National Income in Kenya Between 1986-2009. International Journal of Business and Social Science, 2(21), 275-287.

Omojolaibi, J. A., \& Egwaikhide, F. O. (2013). A Panel Analysis of Oil Price Dynamics, Fiscal Stance, and Macroeconomic Effects: The Case of Some Selected African Countries, Central Bank of Nigeria. Economic and Financial Review, 51(1), 61-91.

Orhunbilge, A. N., \& Tas, N. (2014). Manufacturing Output in Romania: An ARDL Approach. Mediterranean Journal of Social Sciences MCSER Publishing, Rome-Italy, 5(22), 342-353. http://doi.org/10.5901/mjss.2014.v5n22p342

Oriakhi, D. E., \& Ahuru, R. R. (2014). The Impact Of Tax Reform On Federal Revenue Generation in Nigeria. Journal of Policy and Development Studies, 9(1), 92-108. http://dx.doi.org/10.12816/0011185

Oriakhi, D. E., \& Presley, O. P. K. (2013). Tax Incentives and Revenue Productivity of the Nigerian Tax System. International Journal of Development and Economic Sustainability, 1(1), 31-44.

Oyeleke, O. J., \& Adebisi, D. G. (2014). Econometric Analysis of Fiscal Deficit Sustainability of Ghana. Journal of Economics and Sustainable Development, 5(28), 34-41.

Prest, A. R. (1972). Public Finance in Underdeveloped Countries. New York: John Wiley and Sons.

Rena, R., \& Kefela, G. T. (2011). Restructuring A Fiscal Policy Encourages Economic Growth - A Case Of Selected African Countries. Journal of Economics and Business, XIV(2), 23-39.

Wong, J. D. (2004). The Fiscal Impact Of Economic Growth And Development On Local Government Revenue Capacity. Journal of Public Budgeting, Accounting \& Financial Management, 16(3), 413-423. 


\section{Appendix}

\section{Appendix A}

Table A1. Autoregressive distributed lag

\begin{tabular}{llll}
\hline Dependent Variable: LNRGPPT & $\begin{array}{l}\text { Coefficient } \\
\text { (t-Stat. }\end{array}$ & Dependent Variable: LNREALCITA & $\begin{array}{l}\text { Coefficient } \\
(\mathrm{t}-\text { Stat. }\end{array}$ \\
\hline LNRGPPT (-1) & $0.3857(5.4530)^{* * *}$ & LNREALCITA (-1) & $0.3570(4.9360)^{* * *}$ \\
LNRGPPT (-2) & $0.2058(2.7304)^{* * *}$ & LNREALCITA (-2) & $0.1739(2.3894)^{* *}$ \\
LNRGPPT (-3) & $-0.1896(-2.6548)^{* * *}$ & LNRIMPT & $0.1039(1.9826)^{* *}$ \\
LNRGPPT (-4) & $0.1990(3.3357)^{* * *}$ & LNEXPT & $-0.0232(-0.4221)$ \\
LNRIMPT & $-0.02033(-0.3107)$ & LNGDP & $33.8748(3.1446)^{* * *}$ \\
LNREXPT & $0.1836(1.9775)^{* *}$ & LNGDP $(-1)$ & $-45.2497(-2.4309)^{* *}$ \\
LNREXPT (-1) & $0.1222(1.2724)$ & LNGDP $(-2)$ & $-4.1528(-0.2195)$ \\
LNREXPT (-2) & $0.1573(1.6460)$ & LNGDP $(-3)$ & $16.1724(1.4276)$ \\
LNGDP & $-0.0012(-0.0086)$ & Constant & $5.8093(5.6144)^{* * *}$ \\
Constant & $4.3645(6.1174)^{* * *}$ & Adj. R-Squared & 0.78 \\
Adj. R-Squared & 0.76 & & \\
\hline
\end{tabular}

Note. $* * *, * *$, and $*$ indicate significant at $1 \%, 5 \%$ and $10 \%$ respectively.

Table A2. Autoregressive distributed lag

\begin{tabular}{llll}
\hline Dependent Variable: LNRCIDT & $\begin{array}{l}\text { Coefficient } \\
\text { (t-Stat.) }\end{array}$ & Dependent Variable: LNRVATC & $\begin{array}{l}\text { Coefficient } \\
\text { (t-Stat.) }\end{array}$ \\
\hline LNRCIDT (-1) & $0.3225(4.5843)^{* * *}$ & LNRVATC $(-1)$ & $0.0223(0.3106)$ \\
LNRCIDT (-2) & $0.1226(1.6638)^{* *}$ & LNRVATC $(-2)$ & $0.1666(2.4909)^{* *}$ \\
LNRCIDT (-3) & $0.3081(4.3659)^{* * *}$ & LNRVATC $(-3)$ & $0.3623(5.4464)^{* * *}$ \\
LNRIMPT & $0.0842(2.4392)^{* *}$ & LNRVATC $(-4)$ & $0.1024(1.4480)$ \\
LNREXPT & $0.0315(0.7004)$ & LNRIMPT & $0.0973(3.6497)^{* * *}$ \\
LNREXPT (-1) & $-0.0619(-1.3862)$ & LNREXPT & $-0.0220(-0.7974)$ \\
LNGDP & $10.4099(0.1573)$ & LNGDP & $7.5061(1.7899)^{*}$ \\
LNGDP (-1) & $-14.1864(-1.1566)$ & LNGDP $(-1)$ & $-7.1850(-1.7366)^{*}$ \\
LNGDP (-2) & $-1.4083(-0.1142)$ & Constant & $4.8853(4.0689)^{* * *}$ \\
LNGDP (-3) & $-11.3042(-0.9196)$ & Adj. R-Squared & 0.90 \\
LNGDP (-4) & $16.3503(2.1543)^{* *}$ & & \\
Constant & $4.9897(3.3274)^{* * *}$ & & \\
Adj. R-Squared & 0.46 & & \\
\hline
\end{tabular}

Note. ***,**, and $*$ indicate significant at $1 \%, 5 \%$ and $10 \%$ respectively.

Table A3. Autoregressive distributed lag

\begin{tabular}{llll}
\hline Dependent Variable: LNREALTREV & \multicolumn{1}{c}{$\begin{array}{c}\text { Coefficient } \\
\text { (t-Stat.) }\end{array}$} & Dependent Variable: LNREALEXDT & $\begin{array}{c}\text { Coefficient } \\
(\mathrm{t}-S t a t .)\end{array}$ \\
\hline LNREALTREV (-1) & $0.5194(7.4422)^{* * *}$ & LNREALEXDT(-1) & $0.216396 \quad(3.076340)^{* * *}$ \\
LNREALTREV (-2) & $0.2191(3.4555)^{* * *}$ & LNREALEXDT(-2) & $0.306017(4.638631)^{* * *}$ \\
LNRIMPT & $-0.0230(-0.8486)$ & LNRIMPT & $0.324122(3.983394)^{* * *}$ \\
LNREXPT & $0.0704(2.3032)^{* *}$ & LNREXPT & $-0.091920(-0.892348)$ \\
LNGDP & $7.2167(1.7564)^{*}$ & LNREXPT $(-1)$ & $0.215352(2.085697)^{* *}$ \\
LNGDP (-1) & $-7.1449(-1.7480)^{*}$ & LNGDP & $-0.460452(-2.783747)^{* * *}$ \\
Constant & $4.9877(7.2436)^{* * *}$ & Constant & $3.749385(4.6542)^{* * *}$ \\
Adj. R-Squared & 0.81 & Adj. R-Squared & 0.73 \\
\hline
\end{tabular}

Note. $* * *, * *$, and $*$ indicate significant at $1 \%, 5 \%$ and $10 \%$ respectively. 


\section{Appendix B}

Table B1. Granger causality test

\begin{tabular}{lcc}
\hline Null Hypothesis: & F-Statistic & Prob. \\
\hline LNGDP does not Granger Cause LNREALCITA & 11.7211 & 2. E-05 \\
LNGDP does not Granger Cause LNREALGPPT & 3.82649 & 0.0236 \\
LNGDP does not Granger Cause LNREALIMPT & 6.79013 & 0.0014 \\
LNGDP does not Granger Cause LNREALVATC & 11.2928 & 2. E-05 \\
LNREALCIDT does not Granger Cause LNREALCITA & 4.63958 & 0.0108 \\
LNREALTREV does not Granger Cause LNREALCIDT & 3.31173 & 0.0386 \\
LNREALCIDT does not Granger Cause LNREALVATC & 4.79217 & 0.0094 \\
LNREALIMPT does not Granger Cause LNREALCITA & 5.42265 & 0.0051 \\
LNREALCITA does not Granger Cause LNREALIMPT & 3.92332 & 0.0214 \\
LNREALVATC does not Granger Cause LNREALCITA & 9.97192 & 8. E-05 \\
LNREALIMPT does not Granger Cause LNREALEXDT & 3.74159 & 0.0255 \\
LNREALTREV does not Granger Cause LNREALEXDT & 3.63972 & 0.0282 \\
LNREALEXPT does not Granger Cause LNREALGPPT & 15.8518 & 5. E-07 \\
LNREALEXPT does not Granger Cause LNREALTREV & 4.13419 & 0.0175 \\
LNREALVATC does not Granger Cause LNREALGPPT & 3.08211 & 0.0483 \\
LNREALTREV does not Granger Cause LNREALIMPT & 4.43549 & 0.0131 \\
LNREALVATC does not Granger Cause LNREALIMPT & 6.00876 & 0.0030 \\
LNREALIMPT does not Granger Cause LNREALVATC & 3.34840 & 0.0373 \\
\hline
\end{tabular}

Note. only significant granger causality at $5 \%$ is retained.

\section{Copyrights}

Copyright for this article is retained by the author(s), with first publication rights granted to the journal.

This is an open-access article distributed under the terms and conditions of the Creative Commons Attribution license (http://creativecommons.org/licenses/by/4.0/). 